\title{
Efek Intervensi Perilaku Terhadap Manajemen Diri Penderita Diabetes Melitus Tipe 2: Sistematik Review
}

\author{
Yusran Haskas, Suarnianti, Indah Restika
}

\begin{abstract}
ABSTRAK
Behavioral intervention sangat penting dilakukan dalam manajemen diri penderita Diabetes Melitus tipe 2 sebagai intervensi dalam upaya meningkatkan status kesehatan. Manajemen diri merupakan hal penting untuk mempertahankan kontrol gula darah sehingga komplikasi pada penderita DM tipe 2 dapat dicegah. Tujuan: Mengetahui bentuk intervensi perilaku untuk mengukur outcome dari manejemen diri penderita DM tipe 2. Metode: Electronic database dari jurnal yang telah dipublikasi melalui Google Schoolar, ProQuest, PubMed., dan ScienceDirect. Hasil review dari 8 jurnal yang telah dipilih menyatakan bahwa behavioral intervention memberi pengaruh terhadap manajemen diri penderita DM tipe 2 dalam kontrol glikemik. Instrumen penelitian yang digunakan untuk mengukur behavioral intervention pada penelitian kuantitaif yakni kuesioner, melakukan observasi perubahan perilaku, sedangkan pada penelitian kualitatif menggali informasi dengan indepth interview. Hasil: Efek behavioral intervention yang meliputi pemberian edukasi dan self efficacy dapat memfasilitasi peningkatan pengetahuan, pencegahan komplikasi dan meningkatkan kualitas hidup pasien DM tipe 2. Simpulan: efek behavioral intervention sangat efektif dalam meningkatkan manajemen diri penderita DM tipe 2, namun pelaksanaan intervensi perlu dimodifikasi agar didapatkan hasil yang lebih maksimal, salah satunya dengan pemanfaatan terknologi berbasis komunitas.
\end{abstract}

Kata kunci: behavioural intervention, diabetes melitus tipe 2, manajemen diri

\section{ABSTRACT}

Behavioral intervention is very important in the self-management of people with type 2 diabetes as an intervention as well as control in an effort to improve health status. Objectives: To determined the form of behavioral interventions to measure the outcome of self-management of people with type 2 diabetes. Methods: It was an electronic database from journals that have been published through Google Scholar, ProQuest, PubMed., And ScienceDirect. The results of a review of 8 selected journals stated that behavioral intervention had an influence on the self-management of people with type 2 diabetes in glycemic control. The research instrument to measure behavioral intervention in quantitative research is a questionnaire, observing behavior changes, while in qualitative research digging for information with in-depth interviews. Results: The effect of behavioral intervention, which includes providing education and self-efficacy, could facilitate increased knowledge, prevention of complications, and improve the quality of life patients with type 2 diabetes. Conclusion: Behavioral intervention effects are very effective in improving the selfmanagement of patients with type 2 diabetes, but the implementation of the intervention is necessarily modified to get maximum results, one of which is by using community-based technology.

Keyword: Behavioral intervention, self-management, type 2 diabetes mellitus

Affiliasi penulis: Departemen Keperawatan,

Sekolah Tinggi IImu Kesehatan Nani Hasanuddin, Makassar

Korespondensi: Email: yusranhaskas@stikesnh.ac.id

\section{PENDAHULUAN}

Diabetes melitus tipe 2 (DMT2) merupakan kelompok penyakit metabolik dengan karakteristik hiperglikemia, terjadi karena kelainan kerja insulin, sekresi insulin atau kedua-duanya. Sembilan puluh 
persen dari kasus diabetes adalah DMT2 dengan karakteristik gangguan sensitivitas insulin dan/atau gangguan sekresi insulin. DMT2 secara klinis muncul ketika tubuh tidak mampu lagi memproduksi cukup insulin unuk mengkompensasi peningkatan insulin resisten. ${ }^{1}$

Mayoritas dari 382 juta pengidap diabetes berusia antara 40 dan 59, dan $80 \%$ dari mereka hidup di negara berpenghasilan rendah dan menengah. Semua jenis diabetes sedang meningkat, diabetes tipe 2 khususnya: jumlah orang dengan diabetes akan meningkat sebesar $55 \%$ pada tahun 2035. Tambahan 21 juta kasus glukosa darah tinggi dalam kehamilan diperkirakan berkontribusi pada beban diabetes global. Itu setara dengan $17 \%$ kelahiran hidup untuk wanita pada tahun 2013 yang memiliki beberapa bentuk glukosa darah tinggi dalam kehamilan. Dalam istilah manusia maupun finansial, beban diabetes sangat besar, memprovokasi 5,1 juta kematian dan mengambil sekitar USD 548 miliar dolar dalam pengeluaran kesehatan ( $11 \%$ dari total yang dihabiskan di seluruh dunia) pada tahun 2013. Indonesia menempati peringkat ke-7 di dunia dengan 8.5 juta orang penyandang DM pada tahun 2013 . $^{2}$

Tingginya prevalensi DMT2 karena faktor risiko yang tidak dapat dirubah seperti faktor genetik, jenis kelamin, dan umur. Selanjutnya faktor risiko yang bisa dirubah seperti kebiasaan merokok, konsumsi alkohol, aktivitas fisik dan indeks massa tubuh. Resistensi insulin dan defisiensi insulin umumnya ditemukan pada penderita DMT2. ${ }^{3}$ Gejala yang muncul akibat kadar gula yang tidak terkontrol dapat mengganggu aktivitas sehari-hari penderita DMT2 dan menimbulkan gangguan fungsi pada fisik, psikologis dan sosial. Hal-hal tersebut menyebabkan penderita DMT2 merasa kurang sejahtera dan menurunnya kualitas hidup. ${ }^{4}$

Perawatan yang lama serta biaya yang besar menyebabkan motivasi penderita DMT2 selama masa perawatan berfluktuasi sehingga muncul masalah psikologis seperti frustasi, cemas, dan depresi. Masalah psikologis tersebut dapat mempengaruhi motivasi penderita untuk melaksanakan perawatan diri sehingga dapat mempengaruhi efikasi dirinya, maka manajemen perawatan diri penderita tidak berjalan dengan baik. ${ }^{5}$

Peningkatan populasi DM dapat disebabkan karena manajemen diri yang buruk. Salah satu faktor yang sangat berpengaruh dalam pelaksanaan manajemen diri DM adalah pengetahuan pasien tentang DM. Dengan tingkat pengetahuan yang tinggi diharapakan dapat meningkatkan perilaku manajemen diri yang baik. ${ }^{6}$ Jika seseorang mempunyai manajemen diri dengan baik terhadap penyakitnya maka akan mempengaruhi pola kontrol gula dalam darah untuk pasien diabetes, terutama jika gaya hidup serta pola makan tidak tepat. Psikoedukasi merupakan rangkaian pelatihan yang terdiri dari serangkain intervensi psikologis yang bisa diberikan kepada pasien DMT2. ${ }^{7}$

Manajemen diri adalah suatu pendekatan yang sangat efektif dalam mengelola kondisi-kondisi kronik. Manajemen diri sendiri memiliki lima domain utama meliputi manajemen nutrisi, olahraga dan aktivitas fisik, pengawasan glokosa darah, pengobatan medis dan perawatan kaki. ${ }^{8}$ Manajemen diri penderita DM yaitu bagaimana meningkatkan kontribusi dari lingkungan sekitar untuk berperan aktif dalam perawatan kesehatan pasien. Manajemen diri difokuskan pada keterlibatan semua sumber daya yang ada disekitar pasien sehingga akan lebih percaya diri dan meningkatkan perilaku dalam mengelola gejala, perawatan dan perubahan gaya hidup. $^{9}$

Program pendidikan kesehatan merupakan salah satu intervensi untuk manajemen diri penderita DMT2, yang bertujuan untuk peningkatan status fisik maupun psikososial dan berfokus pada penyelesaian masalah dan majemen diri, terdapat banyak ide yang muncul serta sharing pengalaman, berlatih keterampilan berkomunikasi dan memberikan dukungan sosial. ${ }^{10}$ Pendidikan kesehatan meliputi proses menyampaikan informasi dan menanamkan keyakinan dan pada akhirnya akan terbentuk suatu persepsi individu. Pengetahuan yang menyeluruh tentang DMT2, cara pemberian edukasi yang tepat dan melibatkan keluarga, akan memberikan efek positif terhadap pemahaman serta keyakinan diri penderita DMT2 untuk menghadapi penyakitnya. ${ }^{11}$ 
Berdasarkan hal diatas, tujuan dari sistematik review ini untuk mengetahui bagaimana efek dari intervensi perilaku seperti pemberian intervensi

\section{METODE}

Studi ini merupakan tinjauan sistematis dengan sintesis narasi dari temuan utama pada efek intervensi perilaku pada manajemen diri penderita DMT2. Ulasan ini berdasarkan pedoman PRISMA tentang penulisan laporan ulasan sistematik/ sistematic review. ${ }^{12}$ Proses yang digunakan untuk melakukan sistematik review adalah reviewer mencari beberapa artikel jurnal penelitian yang dipublikasi melalui data base elektronik. Adapun database elektronik yang digunakan antara lain: PubMed, ProQuest, dan ScienceDirect dengan rentang waktu tahun 2013 hingga 2018. Proses pemilihan study yang diulas terdiri dari 6 langkah yang ditampilkan pada Diagram 1, yang selanjutnya edukasi, peningkatan self efficacy, psikoedukasi dan intervensi berbasis web untuk mendukung manajemen diri penderita DMT2.

diekslusikan dan pada akhirnya studi yang telah masukan tadi akan selanjutnya disintesis. Untuk penelitian ini, alat ekstraksi data dirancang untuk memandu informasi dari catatan sesuai dengan tujuan penelitian. Data yang diekstraksi pada setiap study yang inklusi meliputi: penulis, tahun, negara, populasi dan setting, desain studi, tujuan penelitian, metode dan intervensi, instrument dan hasil ( Tabel 1). Ulasan sistematik ini menggunakan pedoman untuk menganalisis kualitas pelaporan di antara studi yang dipilih. Pedoman yang digunakan adalah dengan Critical Appraisal Skills Programe tools/ CASP) dan Quality Assesment untuk menilai resiko bias dari studi yang dipilih. ${ }^{13}$

Gambar 1. PRISMA Flow diagram

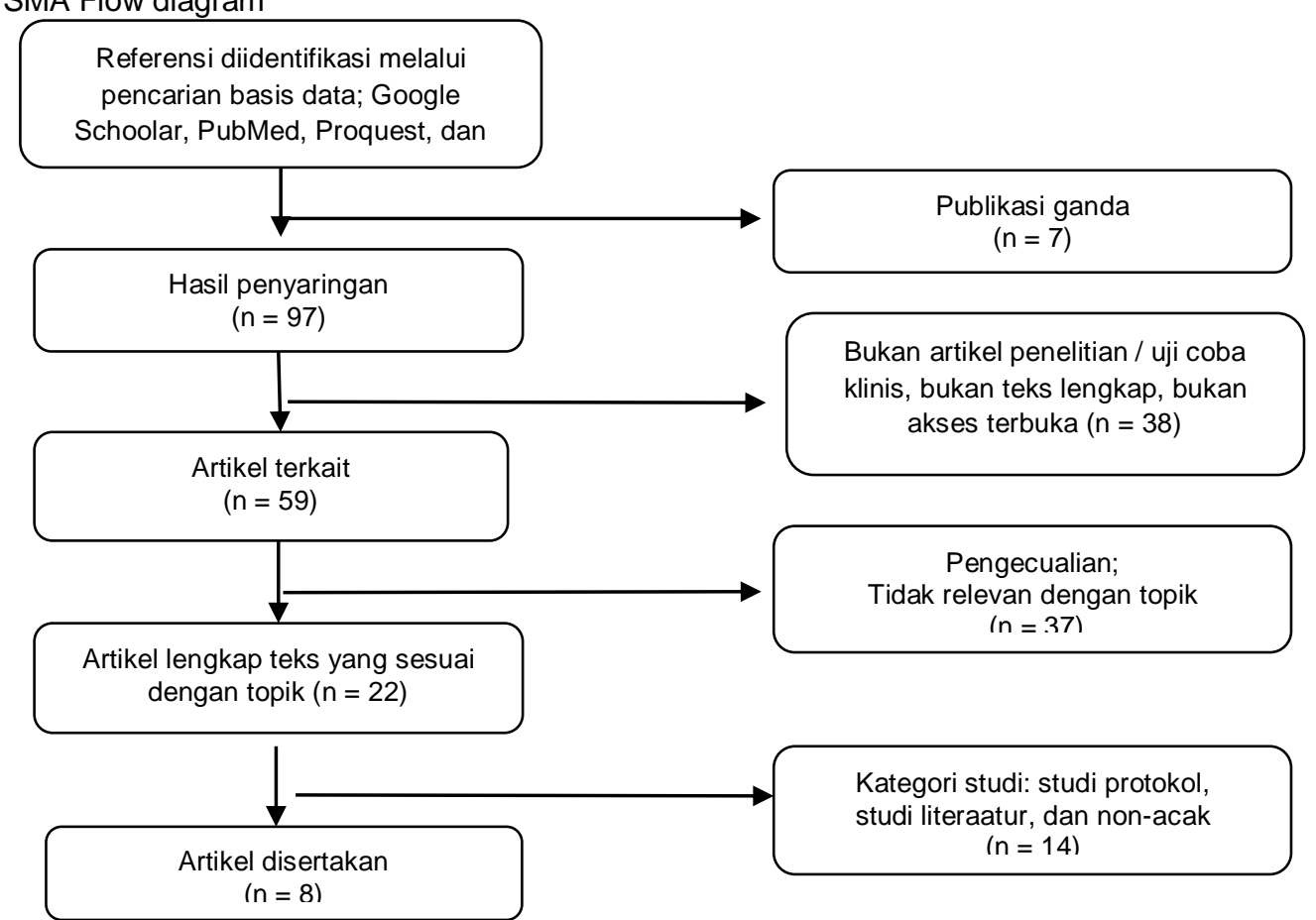


HASIL

Tabel 1. Hasil studi literature efek behavioral intervention pada manajemen diri penderita DM tipe 2

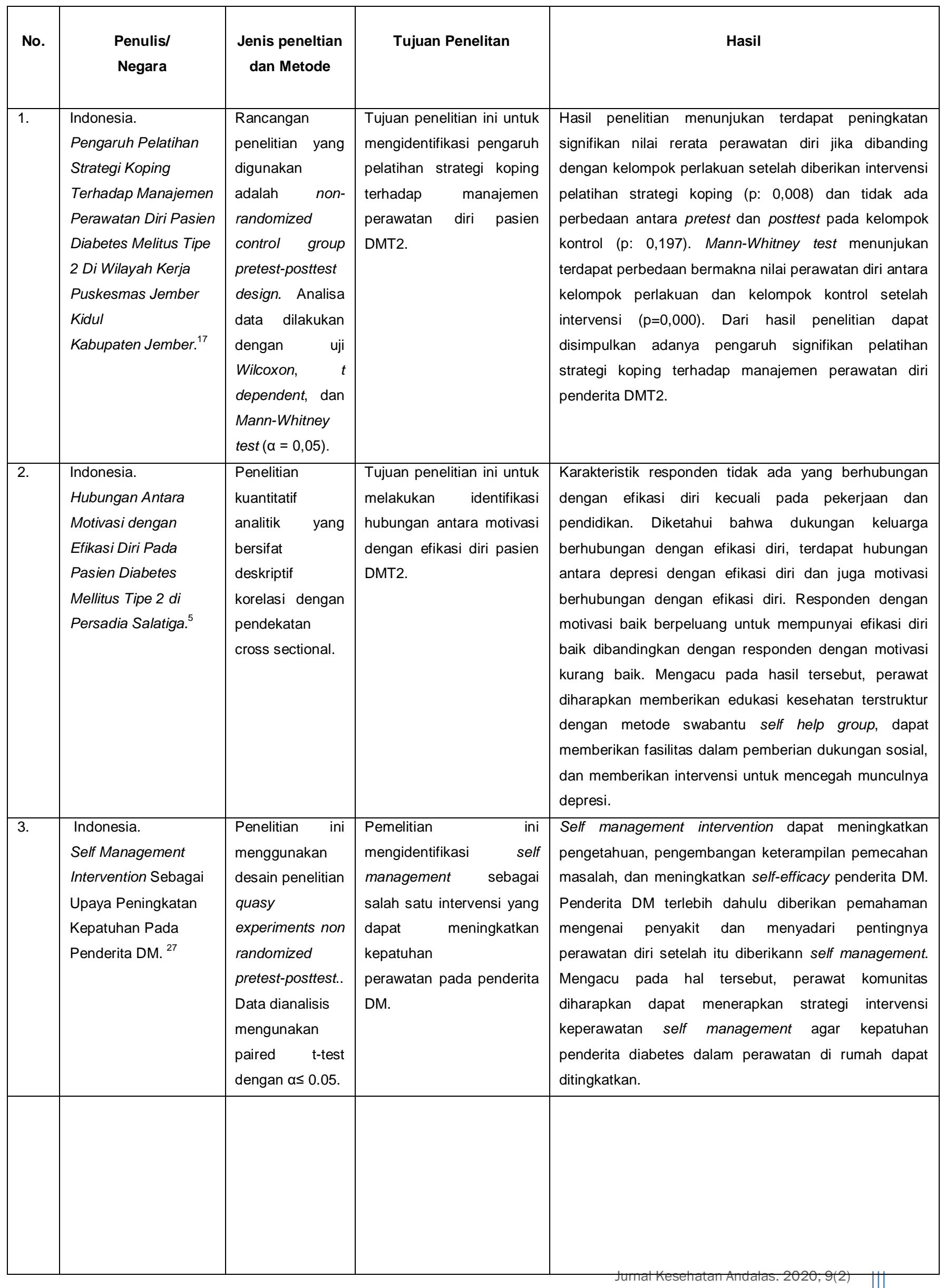




\begin{tabular}{|c|c|c|c|c|}
\hline No. & $\begin{array}{l}\text { Penulis/ } \\
\text { Negara }\end{array}$ & $\begin{array}{l}\text { Jenis peneltian } \\
\text { dan Metode }\end{array}$ & Tujuan Penelitan & Hasil \\
\hline 4. & $\begin{array}{l}\text { Indonesia. } \\
\text { Evaluasi Penerapan } \\
\text { Booklet dan Edukasi } \\
\text { Apoteker pada Pasien } \\
\text { Diabetes Melitus Tipe } \\
2 \text { di Rumah Sakit } \\
\text { Mayapada } \\
\text { Tangerang. }{ }^{14}\end{array}$ & $\begin{array}{l}\text { Penelitian ini } \\
\text { adalah studi } \\
\text { kuantitatif } \\
\text { dengan desain } \\
\text { penelitian } \\
\text { eksperimen }\end{array}$ & 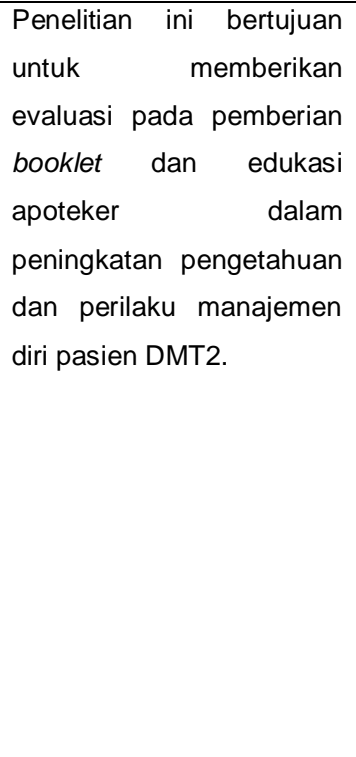 & $\begin{array}{l}\text { Hasil penelitian ini menunjukkan kadar GDP (Glukosa } \\
\text { Darah Puasa) tidak terjadi perubahan yang bermakna } \\
\text { setelah dilakukan intervensi. Sedangkan pada kelompok } \\
1 \text { dan } 2 \text { terjadi peningkatan pengetahuan dan perilaku } \\
\text { manajemen diri. Pada pemberian booklet yang disertai } \\
\text { edukasi oleh apoteker menyebabkan adanya } \\
\text { peningkatan pengetahuan dan perilaku manajemen diri } \\
\text { dibandingkan hanya diberikan booklet. Didapatkan hasil } \\
\text { bahwa pengetahuan tidak berhubungan dengan perilaku } \\
\text { manajemen diri dengan kadar gula darah. Sehingga } \\
\text { terjadi peningkatan pengetahuan dan perilaku } \\
\text { manajemen diri pasien DMT2 pada semua kelompok } \\
\text { intervensi setelah diberikan booklet dan edukasi oleh } \\
\text { apoteker. Namun tidak terdapat hubungan antara } \\
\text { pengetahuan dan perilaku manajemen diri dengan } \\
\text { penurunan GDP. }\end{array}$ \\
\hline 5. & $\begin{array}{l}\text { Indonesia. } \\
\text { Psikoedukasi Untuk } \\
\text { Meningkatkan } \\
\text { Manajemen Diri } \\
\text { Pasien Diabetes } \\
\text { Mellitus Tipe } 2 \text { Di } \\
\text { Puskesmas Kebon } \\
\text { Jeruk. }\end{array}$ & $\begin{array}{l}\text { Metode } \\
\text { penelitian } \\
\text { adalah Quasi- } \\
\text { experimental } \\
\text { dengan desain } \\
\text { The One Group } \\
\text { Pretes-Post Tes } \\
\text { Design. }\end{array}$ & $\begin{array}{lr}\text { Penelitian ini } & \text { bertujuan } \\
\text { untuk } & \text { mengetahui } \\
\text { efektifitas } & \text { dari } \\
\text { psikoedukasi } & \text { untuk } \\
\text { meningkatkan } & \text { manajemen } \\
\text { diri pada } & \text { penyandang } \\
\text { DMT2. } & \end{array}$ & $\begin{array}{l}\text { Hasil penelitian menunjukkan hasil bahwa terdapat } \\
\text { perbedaan antara kelompok pre-tes dan post tes yang } \\
\text { ditunjukkan dengan nilai signifikansi } p<0,05 \text {. Hal ini } \\
\text { menunjukkan bahwa psikoedukasi efektif untuk } \\
\text { peningkatan manajemen diri pada penderita DMT2. } \\
\text { Memberikan intervensi secara psikologis selain } \\
\text { memberikan intervensi secara medis karena terbukti } \\
\text { dapat meningkatkan manajemen dirinya. Berupaya } \\
\text { untuk terus melakukan pengolaan dalam dirinya terkait } \\
\text { dengan penyakit yang dideritanya. Karena dengan } \\
\text { meningkatkan manajemen dirinya baik dari fisik maupun } \\
\text { psikologisnya dapat menstabilkan gula darahnya. }\end{array}$ \\
\hline 6. & $\begin{array}{l}\text { Indonesia. Pengaruh } \\
\text { Intervensi Pendidikan } \\
\text { Kesehatan Dan Self } \\
\text { Efficacy Terhadap } \\
\text { Perubahan Perilaku } \\
\text { Kesehatan Dan } \\
\text { Kadar Gula Darah } \\
\text { Pada Pasien Dm Di } \\
\text { Kabupaten } \\
\text { Manggarai, NTT. }{ }^{15}\end{array}$ & $\begin{array}{l}\text { Desain } \\
\text { penelitian } \\
\text { menggunakan } \\
\text { quasi } \\
\text { eksperimental } \\
\text { pretest dan } \\
\text { posttest }\end{array}$ & $\begin{array}{l}\text { Tujuan penelitian ini untuk } \\
\text { mengetahui pengaruh } \\
\text { intervensi pendidikan } \\
\text { kesehatan dan efikasi diri } \\
\text { terhadap perubahan } \\
\text { perilaku kesehatan dan } \\
\text { kadar glukosa darah pada } \\
\text { pasien diabetes di } \\
\text { Manggarai, Nusa } \\
\text { Tenggara Timur. }\end{array}$ & $\begin{array}{l}\text { Terdapat perbedaan yang signifikan antara intervensi } \\
\text { pendidikan kesehatan dan efikasi diri perubahan } \\
\text { perilaku kesehatan (pengetahuan, diet, aktivitas fisik, } \\
\text { pemantauan glukosa darah, perawatan kaki) dengan } \\
\text { nilai } p<0,05 \text {. Serta terdapat perbedaan yang signifikan } \\
\text { antara intervensi pendidikan kesehatan pada kadar gula } \\
\text { darah (nilai p 0,027). Ada perbedaan yang signifikan } \\
\text { dalam pengetahuan, sikap, diet, aktivitas fisik, } \\
\text { pemantauan glukosa darah, perawatan kaki dan kadar } \\
\text { glukosa darah sebelum dan sesudah intervensi, dengan } \\
\text { nilai p 0,000. Ada perbedaan yang signifikan antara dua } \\
\text { kelompok dalam hal pengetahuan, diet, aktivitas fisik, } \\
\text { glukosa darah, perawatan kaki dan kadar glukosa darah } \\
\text { dengan nilai } p<0,05 \text {. Pendidikan kesehatan harus } \\
\text { direncanakan, diarahkan, berkelanjutan, dan difokuskan } \\
\text { pada perubahan perilaku dan harus menjadi kegiatan } \\
\text { rutin di pusat kesehatan masyarakat. }\end{array}$ \\
\hline
\end{tabular}




\begin{tabular}{|c|c|c|c|c|}
\hline No. & $\begin{array}{c}\text { Penulis/ } \\
\text { Negara }\end{array}$ & $\begin{array}{c}\text { Jenis peneltian } \\
\text { dan Metode }\end{array}$ & Tujuan Penelitan & Hasil \\
\hline 7. & $\begin{array}{l}\text { United Kingdom. } \\
\text { Making and } \\
\text { Maintaining Lifestyle } \\
\text { Changes after } \\
\text { Participating in Group } \\
\text { Based Type } 2 \\
\text { Diabetes Self- } \\
\text { Management } \\
\text { Educations: A } \\
\text { Qualitative Study. }{ }^{16}\end{array}$ & $\begin{array}{lr}\text { Penelitian } & \text { ini } \\
\text { adalah } & \text { studi } \\
\text { kualititatif } & \end{array}$ & $\begin{array}{l}\text { Tujuan penelitian ini untuk } \\
\text { mempelajari bagaimana } \\
\text { peserta membuat dan } \\
\text { mempertahankan } \\
\text { perubahan gaya hidup } \\
\text { setelah berpartisipasi } \\
\text { dalam pendidikan } \\
\text { manajemen diri diabetes } \\
\text { tipe } 2 \text { berbasis kelompok. }\end{array}$ & $\begin{array}{l}\text { Pengetahuan sangat penting untuk membuat perubahan } \\
\text { gaya hidup mengikuti pendidikan. Tiga faktor } \\
\text { mempengaruhi apakah perubahan gaya hidup } \\
\text { dilaksanakan: memperoleh pengetahuan baru, } \\
\text { bertanggung jawab, dan menerima konfirmasi dari gaya } \\
\text { hidup yang sudah sehat. Empat faktor memotivasi } \\
\text { individu untuk mempertahankan perubahan: dukungan } \\
\text { dari orang lain, mengalami efek, takut terjadi komplikasi, } \\
\text { dan pembentukan kebiasaan baru. Selanjutnya, } \\
\text { pengetahuan digunakan untuk membuat dan } \\
\text { mempertahankan perubahan dalam diet, pengobatan, } \\
\text { dan aktivitas fisik. Pengetahuan juga bertindak sebagai } \\
\text { konfirmasi gaya hidup yang sudah memadai. } \\
\text { Pengetahuan menyebabkan tidak ada perubahan jika } \\
\text { diabetes muncul 'tidak menakutkan' atau jika perubahan } \\
\text { tampak terlalu memakan waktu. }\end{array}$ \\
\hline 8. & $\begin{array}{l}\text { Canada. A web- } \\
\text { based intervention to } \\
\text { support } \\
\text { selfmanagement of } \\
\text { patients with type } 2 \\
\text { diabetes mellitus: } \\
\text { effect on self-efficacy, } \\
\text { self-care and diabetes } \\
\text { distress. }^{18}\end{array}$ & $\begin{array}{l}\text { Menggunakan } \\
\text { studi kohort dan } \\
\text { wawancara } \\
\text { kualitatif }\end{array}$ & $\begin{array}{l}\text { Penelitian ini untuk } \\
\text { mengetahui pengaruh } \\
\text { intervensi manajemen diri } \\
\text { pasien berbasis web pada } \\
\text { psikologis (self-efficacy, } \\
\text { kualitas hidup, perawatan } \\
\text { diri) dan hasil klinis }\end{array}$ & $\begin{array}{l}\text { Skor efikasi diri tidak meningkat secara signifikan lebih } \\
\text { dari yang diharapkan setelah sembilan bulan, juga tidak } \\
\text { hasil klinis. Analisis wawancara ( } n=21 \text { ) mengungkapkan } \\
\text { empat tema: 1) mediator penggunaan situs web; 2) pola } \\
\text { penggunaan situs web, termasuk peran blog dalam } \\
\text { mengarahkan lalu lintas situs; 3) umpan balik di situs } \\
\text { web; dan 4) mekanisme potensial untuk efek situs web. } \\
\text { Situs web manajemen diri untuk penderita DMT2 tidak } \\
\text { meningkatkan efikasi diri. Penggunaan situs web } \\
\text { terbatas. Meskipun dirasakan keandalannya, } \\
\text { ketersediaan blog dan pengingat yang dikirim melalui } \\
\text { email menarik orang ke situs web, para peserta berjuang } \\
\text { dengan DMT2, bersaing dalam kehidupan mereka, dan } \\
\text { aksesibilitas situs web menjadi hambatan dalam } \\
\text { penggunaannya. }\end{array}$ \\
\hline
\end{tabular}

Dari 8 penelitian yang terpilih, penelitian dilakukan di Indonesia dan negara lain. Metode penelitian yang digunakan yaitu Quasi-Experiments non randomized pretest posttest, Quasy Experimental the one group pretest post test design, cross sectional dan studi kualitatif $(n=8)$. Artikel penelitian ini dipublikasikan dalam rentang 2013 sampai 2018. Intervensi perilaku untuk manajemen diri penderita DMT2 adalah sebagai berikut:
1. Behavioural intervention dengan memberikan edukasi dan peningkatan self efficacy

DSME (Diabetes Self Management Education) merupakan salah satu bentuk edukasi yang efektif diterapkan kepada pasien DM karena dapat meningkatkan pengetahuan, perilaku dan sikap penderita dalam melaksanakan perawatan secara mandiri. Informasi yang diberikan merupakan suatu penunjang untuk dapat meningkatkan pengetahuan, sehingga muncul kesadaran agar mempunyai perilaku yang sesuai dengan harapan. ${ }^{5}$ 
Pada penerapan booklet dan edukasi apoteker yang dilaksanakan dapat terjadi peningkatan pengetahuan dan perilaku dalam manajemen diri pasien DMT2 pada semua kelompok intervensi. Booklet yang digunakan untuk pemberian edukasi diambil dari telah terstandarisasi dan diketahui mampu memberikan pengetahuan pasien DM. ${ }^{14}$ Self efficacy yang tinggi juga sangat berpengaruh dalam manajemen penyakit DMT2 karena individu memiliki keyakinan akan kemampuan yang dimilikinya yang berpengaruh terhadap pemilihan perilaku, terhadap fungsi manusia melalui beberapa cara antara lain pemilihan terhadap perilaku, pola pikir dan respon, ide atau gagasan. Individu dengan self efficacy yang rendah secara umum memiliki kecenderungan menghindari tugas, sementara yang tinggi biasanya melaksanakan tugas yang mempengaruhi kehidupannya. ${ }^{15}$

Pengetahuan yang diperoleh selama pendidikan manajemen diri diabetes digunakan oleh peserta untuk mempertahankan perubahan dalam diet, pengobatan, dan aktivitas fisik. Pengetahuan juga dapat bertindak sebagai konfirmasi bahwa gaya hidup seseorang cukup sehat. ${ }^{16}$

\section{Behavioural intervention dengan strategi koping}

Pelatihan strategi koping dapat diaplikasikan untuk meningkatkan manajemen diri pada pasien

\section{PEMBAHASAN}

Beberapa sintesa yang direview dapat diketahui bahwa intervensi perilaku dengan pemberian edukasi dan self efficacy sangat efektif, karena penderita DMT2 yang memiliki pengetahuan tentang perawatan diri memiliki kontrol glikemik jangka panjang yang lebih baik, selain itu pemberian edukasi tersebut dapat terintegrasi secara keseluruhan dengan proses manajemen diri penderita DMT2 secara umum melalui dilaksanakannya pengaturan diet, pengobatan, aktifitas, kontrol gula darah, dan perawatan kaki. Selain pemberian edukasi, pemberian pelatihan kepada penderita DM juga dapat memberikan peningkatan pengetahuan dan self-efficacy penderita secara signifikan dalam pengontrolan
DM. Diketahui bahwa manajemen perawatan diri pasien DMT2 dapat dipengaruhi oleh bagaimana strategi koping pasien. Perawatan diri meningkat setelah pemberian intervensi pelatihan strategi koping. ${ }^{17}$

\section{Behavioural intervention melalui psikoedukasi}

Psikoedukasi efektif untuk meningkatkan manajemen diri pada penderita DMT2 dengan memberikan intervensi secara psikologis selain memberikan intervensi secara medis karena terbukti dapat meningkatkan manajemen dirinya. Berupaya untuk terus melakukan pengolaan dalam dirinya terkait dengan penyakit yang dideritanya seperti menstabilkan gula darahnya. ${ }^{7}$

4. A web-based intervention untuk manajemen diri Penatalaksanaan diabetes mellitus kompleks dan melibatkan pengendalian berbagai faktor risiko yang menjadi penyebab komplikasi. Mengingat bahwa pasien menyediakan sebagian besar perawatan diabetes mereka sendiri, pelatihan manajemen diri pasien adalah strategi penting untuk meningkatkan kualitas perawatan. Intervensi berbasis web memiliki potensi untuk menjembatani kesenjangan dalam perawatan diri dan manajemen diabetes. $^{18}$

serta frekuensi pengukuran kadar gula darah, dalam menjaga pola makan, dan juga perawatan.

Sejalan dengan penelitian Yuanita et al (2018) bahwa salah satu hal yang memegang peranan penting dalam penatalaksanaan DMT2 adalah edukasi atau pendidikan kesehatan. Edukasi kepada pasien DMT2 penting dilakukan sebagai tindakan awal pengendalian. Diabetes Self Management Education (DSME) merupakan suatu edukasi yang umumnya digunakan serta efektif dalam meningkatkan kualitas hidup penderita memperbaiki hasil klinis. Pada proses DSME penderita DM diberikan pengetahuan mengenai strategi dalam perawatan diri untuk mengontrol 
metabolik, mencegah komplikasi, dan meningkatkan kualitas hidup penderita DM. ${ }^{19}$

Pendidikan kesehatan sangat penting dalam mengelola dan manajemen diabetes melitus. Pendidikan kesehatan pada pencegahan primer diberikan kepada masyarakat dengan risiko tinggi, secara sekunder diberikan untuk kelompok penderita DM, serta untuk pencegahan tersier diberikan untuk penderita yang sudah menderita DM dengan penyulit menahun. ${ }^{20}$

Pemberian edukasi untuk manajemen diri penderita diabetes dapat merubah perilaku penderita melalui pemberian informasi, sehingga timbul kesadaran dalam berperilaku sesuai dengan harapan. ${ }^{19}$

Hal tersebut diperkuat oleh penelitian yang dilakukan oleh Rahman et al (2017) diketahui bahwa pada pasien DM perubahan perilaku sangat diperlukan untuk mencapai tujuan dari pengelolaan DM yaitu kadar gula dalam batas normal. Berdasarkan pada konsep Health Promotion Models (HPM), efikasi diri pada pasien akan mempengaruhi pasien dalam berperilaku dan berkomitmen. Penelitian lainnya tentang metanalisis pelatihan manajemen diri dan kualitas hidup menunjukkan bahwa efikasi diri pada pasien DM berhubungan dengan manajemen diri pasien sehingga akan berdampak pada terpeliharanya kualitas hidup pasien. ${ }^{21}$

Pemberian intervensi model psikoedukasi secara keseluruhan dapat meningkatkan efikasi diri penderita DM tipe 2. Locus of control internal yang tinggi pada diri penderita diabetes menimbulkan keyakinan bahwa keberhasilan mengendalikan diabetes merupakan hasil usaha dirinya sendiri. ${ }^{22}$ Hal berbeda dikemukakan oleh Yosdimyati \& Hariyono (2018) bahwa psikoedukasi dapat meningkatkan kontrol glukosa darah dengan cukup baik, tetapi masih membutuhkan integrasi dengan komponen lain yang terkait dengan perawatan dan pengobatan pada penderita DM. Psikoedukasi tidak cukup signifikan dalam meningkatkan motivasi untuk memulihkan pasien DM, akan tetapi dengan peningkatan pengetahuan dan psikologi penderita DM, diharapkan bahwa mereka dapat meningkatkan motivasi mereka untuk mendukung peningkatan kemampuan perawatan diri, mengubah perilaku dan dapat melaksanakan kegiatan untuk mempertahankan kontrol glikemik. ${ }^{23}$

Semakin adekuat Diabetes Self Management maka semakin baik kualitas hidup pasien DMT2. Sebagian besar rencana perawatan diabetes meliputi diet, aktivitas fisik dan penggunaan insulin atau obat oral jika diperlukan. Self management merupakan aktifitas yang kompleks termasuk kemampuan dalam mengontrol suatu kondisi dan afek kognitif, perilaku dan respon emosional dalam mempertahankan kebutuhan kualitas hidup. ${ }^{24}$

Manajemen diri penderita DMT2 memiliki salah satu aspek penting yaitu pemecahan masalah yang berhubungan dengan cara dan waktu yang tepat dalam mengontrol kadar glukosa tubuh. Penderita yang mengetahui bahwa diabetes dapat menimbulkan komplikasi akan cenderung melakukan manajemen diri yang tinggi. ${ }^{22}$ Manajemen diri penderita DMT2 memiliki salah satu aspek penting yaitu pemecahan masalah yang berhubungan dengan cara dan waktu yang tepat dalam mengontrol kadar glukosa tubuh. Penderita yang mengetahui bahwa diabetes dapat menimbulkan komplikasi akan cenderung melakukan manajemen diri yang tinggi. ${ }^{22}$ Peranan faktor manajemen diri dalam memperoleh gula darah yang stabil pada penderita adalah hal yang cukup penting. Manajemen diri sendiri memiliki lima domain utama meliputi manajemen nutrisi, olahraga dan aktivitas fisik, pengawasan glukosa darah, pengobatan medis dan perawatan kaki. ${ }^{25}$

Intervensi lain yaitu intervensi berbasis web yang berpotensi untuk menjembatani kesenjangan dalam perawatan diri dan manajemen diabetes dengan memanfaatkan teknologi yang merupakan alat media berupa smartphone dalam penanganan DM sehingga tidak berkelanjutan pada komplikasi. Pemanfaatan smartphone dapat berfungsi sebagai alat untuk meningkatkan hasil kesehatan melalui aplikasi yang berisi informasi kesehatan terkait DM, video terapi modalitas pengendalian glukosa, panduan diet sehat untuk pengendalian berat badan sesuai dengan IMT dan menu profil riwayat 
penderita diabetes mellitus, namun aplikasi smartphone kemungkinan harus melakukan peninjauan ulang catatan glukosa secara online serta penyedia harus mempertimbangkan untuk menerapkan intervensi berbasis teknologi ini di klinik untuk mengatasi masalah umum pada penderita DM. ${ }^{18,26}$

Intervensi perilaku dengan berbagai metode

\section{SIMPULAN}

Sistematik review ini memfokuskan pada intervensi perilaku untuk manajemen diri penderita DMT2, karena dengan meningkatkan manajemen diri pada penderita baik dari fisik maupun psikologis dapat menstabilkan gula darahnya. Dari hasil review diketahui bahwa pemberian edukasi dan efikasi diri merupakan komponen penting yang

\section{DAFTAR PUSTAKA}

1. Decroli E. Diabetes melitus tipe 2. Padang; Pusat Penerbit Bagian IImu Penyakit Dalam Fakultas Kedokteran Universitas Andalas; 2019.

2. International Diabetes Federation (IDF). Diabetes atlas. Sixth edition. 2013. Epub ahead of print. 2013. p. 1-160.

3. Fatimah RN. Diabetes melitus tipe 2. Jurnal Majority. 2015;4(5): 93-101.

4. Kusumadewi MD. Peran stresor harian, optimisme dan regulasi diri terhadap kualitas hidup individu dengan diabetes melitus tipe 2 . Psikoislamika - J Psikol dan Psikol Islam. 2011; $8: 43-61$

5. Kusuma H, Hidayati W. Hubungan antara motivasi dengan efikasi diri pada pasien diabetes mellitus tipe 2 di Persadia Salatiga. J Keperawatan Med Bedah. 2013;1:132-41.

6. Kusnanto K, Sundari PM, Asmor CP, Arifin H. Hubungan tingkat pengetahuan dan diabetes self-management dengan tingkat stres pasien diabetes melitus yang menjalani diet. $J$ Keperawatan Indonesia. 2019;22(1):31-42

7. Wijaya YD, Widiastuti M. Psikoedukasi untuk meningkatkan manajemen diri pasien diabetes mellitus tipe 2 di Puskesmas Kebon Jeruk. dikembangkan dengan tujuan untuk meningkatkan manajemen diri penderita DMT2. Oleh karena itu, manajemen diri merupakan bagian terpenting dari perawatan diabetes, karena manajemen diri penderita diabetes melitus tipe 2 erat kaitannya dengan faktor perilaku dari penderita serta faktor lingkungan dalam kegiatan sehari-hari yang dilakukan oleh penderita DMT2.

mempengaruhi perilaku manajemen diri pada penderita DMT2. Kedepannya intervensi berbasis web ataupun menggunakan smartphone yang berisi aplikasi dapat digunakan petugas kesehatan untuk implementasi pengendalian diabetes mellitus serta untuk mencegah komplikasi pada penderita DMT2.

J Psikol; vol:15(2).

8. Wang CM, Inouye J, Davis J, Wang CY. Diabetes knowledge and self-management effects on physiological outcomes in type 2 diabetes. Nurs Forum. 2013;48(4):240-7.

9. Warsito BE. Peningkatkan kemampuan pasien dalam self manajemen. Prosiding Seminar Nasional Keperawatan " Pengembangan Self Management pada Pelatanan Kesehatan". 2018:6-10. ISSN 978-602-5560-81-1.

10. Sudirman AA. Diabetes mellitus, diabetes self management education ( DSME), and self care diabetik. Proceeding Gorontalo Int Nurs Conf. $2017 ; 1-11$

11. Huzaimah N. Model psikoedukasi untuk meningkatkan pemahaman dan efikasi diri penderita diabetes mellitus tipe 2 . Wiraraja. 2018;8(1):19-26

12. Moher D, Liberati A, Tetzlaff J, Altman DG. Preferred reporting items for systematic reviews and meta-analyses: The PRISMA statement. PLoS Med; 2009;8(5): 336-41.

13. Higgins JP, Green S. Cochrane handbook for systematic reviews of interventions: Cochrane book series. 2008. Epub ahead of print. 2008. DOI: $10.1002 / 9780470712184$. 
14. Sagala RM, Arozal W, Sauriasari R, Keban S. Evaluasi penerapan booklet dan edukasi apoteker pada pasien diabetes melitus tipe 2 di rumah sakit Mayapada Tangerang. Pharm Sci Res. 2017;4:102-10.

15. Ningsih OS. Pengaruh intervensi pendidikan kesehatan dan self efficacy terhadap perubahan perilaku kesehatan dan kadar gula darah pada pasien DM di Kabupaten Manggarai, NTT. Wawasan Kesehatan. 2016;1:107-25.

16. Rise MB, Pellerud A, Rygg L $\varnothing$, Steinsbekk A. Making and maintaining lifestyle changes after participating in group based type 2 diabetes self- management educations: a qualitative study. PLoS One. 2013;8(5):1-7.

17. Widayati $\mathrm{N}$, Wantiyah, Wuryaningsih EW. Pengaruh pelatihan strategi koping terhadap manajemen perawatan diri pasien diabetes melitus tipe 2 di wilayah kerja Puskesmas Jember Kidul Kabupaten Jember. IKESMA. 2015;11(2): 139-50.

18 Catherine HY, Parsons J, Mamdani M, Lebovic G, Hall S, Newton D, Straus SE. A web-based intervention to support selfmanagement of patients with type 2 diabetes mellitus: Effect on self-efficacy, self-care and diabetes distress. BMC Med Inform Decis Mak. 2014;14:1-14.

19. Yuanita A, Wantiyah, Susanto T. Pengaruh diabetes self management education (DSME) terhadap resiko terjadinya ulkus diabetik pada pasien rawat jalan dengan diabetes mellitus (DM) tipe 2 di RSD dr. Soebandi Jember. J Media Kesehat. 2014;2(1):119-24.

20. Fatimah RN. Anti-oxidant and anti-diabetic activities of ethanolic extract of Primula Denticulata Flowers. Indones J Pharm. 2016;
27:74-9.

21. Rahman HF, Yulia Y, Sukarmini L. Efikasi Diri, kepatuhan, dan kualitas hidup pasien diabetes melitus tipe 2 ( self efficacy, adherence, and quality of life of patients with type 2 diabetes ). e-Jurnal Pustaka Kesehat. 2017;5:108-13.

22. Oktarinda RLD, Surjaningrum ER. Hubungan antara persepsi penyakit dengan manajemen diri pada penderita diabetes yang memiliki riwayat keturunan. J Psikol Klin dan Kesehat Ment. 2014;3(1):25.

23. Yosdimyati L, Hariyono $H$. Pengaruh psikoedukasi terhadap motivasi sembuh dan glukosa darah pada penderita diabetes mellitus tipe 2 dengan pendekatan teori adaptasi RoY. J Keperawatan. 2018;15(1):41-50.

24. Laili N. Hubungan diabetes self-management dengan kualitas hidup pasien diabetes mellitus tipe 2 di RS Amelia Pare Kediri. J IIm Keperawatan Stikes Hang Tuah Surbaya. 2017; 12.:1077-83

25. Elpriska E. Pengaruh stres, dukungan keluarga dan manajemen diri terhadap komplikasi ulkus kaki diabetik pada penderita DM tipe 2. Idea Nurs J. 2016; 7(1): 20-5.

26. Andriyanto A, Hidayati RN. Literature review: Pemanfaatan media promosi kesehatan (smartphone) dalam mencegah dan mengendalikan kadar gula diabetes tipe 2 (Literature review: Utilization of health promotion media (smartphone) to prevent and control glucose type 2 diabetes). Jurnal Ners dan Kebidanan. 2018; 5(2):172-7.

27. Kholifah SN. Self management intervention sebagai upaya peningkatan kepatuhan pada penderita DM. J Ners. 2014; 9(1): 143-50. 